\title{
Abstraction: Death by a Thousand Cuts
}

\author{
Diana Khamis ${ }^{1}$ \\ (Rheinische-Friedrich-Wilhelms-Universität Bonn)
}

If we want to ask ourselves whether nature is facing a crisis and whether there is still place for a philosophy of nature, we should also ask ourselves what definition of "nature" are we using to approach this inquiry. Philosophy, it seems, has deferred the standard definition of nature to physical sciences, where nature is whatever these sciences study. That does not, however, cater to the philosophical dimension of the question "what is nature?" To address that dimension in the philosophical landscape of modern and contemporary philosophies, Immanuel Kant might perhaps be a better starting point - the Critique of Pure Reason tells us that "nature is nothing in itself but a sum of appearances, hence not a thing in itself but merely a multitude of representations of the mind." 2 This is true at least of the nature presented in the first Critique - Kant's project does get more complex in the third Critique, but even this complexity comes arguably largely, if not entirely from our moral faculties and human freedom. This position seems to be as damning as it gets for nature - if nature is to be taken as a multitude of appearances, then it loses all independence, and we do not need a philosophy of nature or a serious engagement with it. With nature as sum of appearances, all we need to (and even can) philosophical-

\footnotetext{
1.diana.khamis@gmail.com

2 Immanuel Kant, Critique of Pure Reason, trans. Paul Guyer and Allen W. Wood, Cambridge: Cambridge University Press, 1998, p. 236.
}

Philosophica, 47, Lisboa, 2016, pp. 43-59. 
ly investigate is how things appear, or even more precisely - how they are "taken" by a subject. Even if nature, instead of being conceived as the sum of appearances, is taken as a limited domain of objects, this is still fairly damning: it permits to draw a line at a certain point of the investigation and claim that nature goes no further, and that whatever phenomena are investigated within this "further" can be investigated without recourse to nature. Either way, on this view of nature, there is clearly not much room for Naturphilosophie or even for nature being given a significant role in philosophy. If a Naturphilosophie is to be attempted at all, a different view of nature is needed.

In what follows, I will present such a view developed partly in response to Kantian philosophy, one which takes nature to be a lot more than just a sum of things - a productive force. This view of nature has been put forward by F.W.J. Schelling. I would like to argue that Schelling's philosophy - not only what has been considered his "Naturphilosophie phase", but also certain works from the later stages of his oeuvre - gives us a conception of nature such that Naturphilosophie remains viable and nature remains relevant, indeed, inevitably so. In a Schellingian scheme of presenting nature, however, one threat to Nature remains - namely, abstraction. This can be potentially problematic for philosophical thinking, therefore, in the last part of my paper, I will look at how one is to approach abstraction as a useful tool, and not as an instrument of destruction.

\section{Naturphilosophie}

The view of Nature Schelling develops in his Naturphilosophie is partly a response to Kant and partly a response to mechanistic views of nature. The problem with mechanism, Schelling claims, is its inability to explain how nature arises. The mechanical nature is a network of causes and effects, all affecting each other in the same way, and such a network itself could only have been brought into existence by an external cause. Schelling, with his obvious reluctance to simply announce that God the creator was this cause, considers this feature to be a deadly problem of 
mechanism. ${ }^{3}$ The first Critique's view of nature as a sum of appearances, on the other hand, was rejected by Schelling not only because Kant had considered nature from different angles in the third Critique, as well as in the Metaphysical Foundations of the Natural Sciences, but also fundamentally because no matter what Kant does, he does not convincingly solve the problem of the gap between the transcendental free subject and the allegedly unfree nature. This gap is, for Schelling, particularly problematic, since he wants to philosophically engage with the fact that human beings are, apparently, natural creatures - a claim even Kant would not wholly deny.

In order to solve the problem of the emergence and development of natural things, Schelling proposes a different view of nature - that of a productive force operating in powers, rather than simply an indefinitely extended series of all things. This is - to put it simply - because if faced with the choice between the primacy of either things or powers, one chooses the primacy of things, then, as Iain Hamilton Grant has put it, one's "ontology becomes dualistic, comprising powers irreducible to substances and substances without powers as inert substrata for them, but with no account of a vinculum to bond them." ${ }^{4}$ It is far more productive - in the face of mechanism, and in the face of addressing the problem of becoming - to choose powers as the currency of a Naturphilosophie, and this is what Schelling does.

3 F.W.J. Schelling, Ideas for a Philosophy of Nature, trans. Peter Heath and Errol E. Harris, Cambridge: Cambridge University Press, 1995, p. 30: "The dogmatist, who assumes everything to be originally present outside us (not as coming to be and springing forth from us) must surely commit himself at least to this: that what is external to us is also to be explained by external causes. He succeeds in doing this, as long as he remains within the nexus of cause and effect, despite the fact that he can never make it intelligible how this nexus of causes and effects has itself arisen. As soon as he raises himself above the individual phenomenon, his whole philosophy is at an end; the limits of mechanism are also the limits of his system." [Id., Sämmtliche Werke, Bd. II, Stuttgart: J.G. Cotta'scher Verlag, 1857, p. 40: „Der Dogmatiker, der alles als ursprünglich außer uns vorhanden (nicht als aus uns werdend und entspringend) voraussetzt, muß sich doch wenigstens dazu anheischig machen, das was außer uns ist auch aus äußern Ursachen zu erklären. Dieß gelingt ihm, so lange er sich innerhalb des Zusammenhangs von Ursache und Wirkung befindet, unerachtet er nie begreiflich machen kann, wie dieser Zusammenhang von Ursachen und Wirkungen selbst entstanden ist. Sobald er sich über die einzelne Erscheinung erhebt, ist seine ganze Philosophie zu Ende; die Grenzen des Mechanismus sind auch die Grenzen seines Systems."]

4 Iain Hamilton Grant, "Does Nature stay what it is?" in The Speculative Turn: Continental Materialism and Realism, eds. Levi Bryant, Graham Harman, Nick Srnicek, Melbourne: re.press, 2010, p. 67. 
Moreover, as early as Schelling's First Outline of the System for a Philosophy of Nature all philosophy is said to be inquiring after an unconditioned, Naturphilosophie being no exception: it enquires after nature as unbedingt, i.e. not nature as an object, or "the sum total of existence, [for then] it would therefore be impossible to view Nature as an unconditioned", ${ }^{5}$ but "Nature only as active, [as an infinite product]for it is impossible to philosophize about any subject which cannot be engaged in activity." If nature were inactive, if nature were completely inert, no philosophy of it would have been even possible. So, in Schelling, we have a nature that, being productivity, must be approached in terms of productive forces as opposed to discrete units. This conviction remains with Schelling, somewhat surprisingly and contrary to expectations, all throughout his philosophical work, so that in the very late text Darstellung des Naturprozesses (1843-44) nature is still a clear concern, and is still defined as activity - this time, as a function of the three potencies, three moments which every process of creation passes through:

At the beginning of this entire explication, we had three moments emerge separately from the idea so that it actualizes itself in returning to unity. The separation and reunification of these moments is nature. The reproduction of unity is for it the end and the goal of nature. ${ }^{7}$

The approach Schelling takes towards nature obviously varies from his earliest to his latest texts in its specifics; however, consequent on the broader view of nature as productivity, certain features remain. Two of the most prominent ones are the primacy of power over body, and the non-existence of any fundamental level or unit in nature. These two features are tightly related. They stem from Schelling's desire to explain how nature - which

5 F.W.J. Schelling, First Outline for a System of the Philosophy of Nature, trans. Keith R. Peterson, New York: SUNY Press, 2004, p. 14. [Id., Sämmtliche Werke, Bd. III, Stuttgart: J.G. Cotta'scher Verlag, 1858, p. 13: „Nun ist aber nach allgemeiner Uebereinstimmung die Natur selbst nichts anderes als der Inbegriff alles Seyns; es wäre daher unmöglich, die Natur als ein Unbedingtes anzusehen [...]"].

6 Ibid. [Id., Sämmtliche Werke, Bd. III, p. 13: „Wir kennen die Natur nur als thätig, - denn philosophieren läßt sich über keinen Gegenstand, der nicht in Thätigkeit zu versetzen ist."]

7 Id., Sämmtliche Werke, Bd. X, Stuttgart: J.G. Cotta'scher Verlag, 1861, p. 307: „Im Anfang dieser ganzen Entwicklung, liessen wir die Idee auseinander treten in ihre Momente, damit sie Wiederkehr in die Einheit sich verwirkliche. Das Auseinandergehen und successiv Wiedereinswerden dieser Momente ist die Natur. Die Wiederherstellung der Einheit ist ihre Ende und Zweck der Natur.“ 
for him is to an overwhelmingly large extent self-generated - arises. The combination of atomism (fundamental unit) and somatism (bodies are primary to powers) gives philosophy a mere substratum without potency to work with. In this case, philosophy is unable to trace the generation of this substratum - both in the sense that it is not able to investigate how the substratum came about, and in the sense that it is able to explain the generation of powers this substratum possesses. Even when it comes to powers, however, taking any level of natural activity as "fundamental", i.e. one below which there is no activity whatsoever is, for Schelling, problematic - the problem is one of explaining how this "fundamental" level arose and why the philosopher has chosen it as fundamental. This issue will be discussed in more detail later in the paper.

As an aside, one might say that on this account, Schelling's philosophy fares no better than mechanism. With the former we have to recourse to more and more powers, just as with this latter, in order to explain the generation and powers of certain bodies, we had to constantly fall back on other bodies. And yet, the issue is different. Mechanism postulates an endless chain that could not possibly be endless - some cause, at the beginning of the chain, would have to be external. Of powers, on the other hand, there can be an unending chain; Schelling would be perfectly fine with such a chain. Indeed, this could well be why, when discussing the beginning of the world in the Weltalter, Schelling speaks of eternal past and eternal future. ${ }^{8}$

In any case, we now have a sketch for what nature is according to Schelling's Naturphilosophie: it is unconditioned productivity, it deals in powers; it has no fundamental level to its activity. However, how are we to think this unconditioned nature? How does such a conception fit together with philosophy's requirement for abstract thought? It would seem that this formidable nature would be killed by abstraction. I turn to the question of what abstraction is for Schelling and how we are to deal with it.

\section{The Culprit}

It would seem that nature is destructible in a multitude of ways. Only one of these ways, however, is a destruction of nature, as opposed to that of natural products. The systematic undermining of our precarious envi-

See F.W.J. Schelling, Ages of the World, trans. Jason M. Wirth, New York: SUNY Press, 2000, pp. 38-39. 
ronmental balance, loss of animal and plant species, genetic modification, robotics - all those at their best (or maybe worst) only destroy a part of nature. Nothing short of the comically depraved plans of movie villains who seek and have means to literally destroy everything that exists, to return $\mathrm{All}$ - not just every single thing, but the All, including the very processes of production/annihilation and the forces behind them - into the void could possibly be said to annihilate nature. Even then, probably not quite. This position is consequent on Schelling's view of nature as unconditioned presented above. This nature cannot be annihilated, i.e. its functioning cannot be stopped, simply with and through the actions of human animals forming a part of it. Only a total stoppage of this activity could be nature's undoing. In his work, Schelling also gives us hints as to the potential perpetrator of the undoing: abstraction. Schelling's famous Freiheitsschrift diagnosis "[t]he whole of modern European philosophy since its inception (through Descartes) has this common deficiency - that nature does not exist for it" "blames modern European philosophy for a very specific error - an attempt to think nature out of relevance, even out of existence through abstraction, ${ }^{10}$ insisting:

[...] Spinoza's realism is as abstract as the idealism of Leibniz. Idealism is the soul of philosophy; realism is its body; only the two together constitute a living whole. Realism can never furnish the first principles but it must be the basis and the instrument by which idealism realizes itself and takes on flesh and blood. If a philosophy lacks this vital basis, usually a sign that the ideal principle was but weak from the outset, it then loses itself in those systems whose attenuated concepts of aseity, modality, etc., stand in the sharpest contrast to the vital power and fullness of reality. On the other hand, where the ideal principle really operates to a high degree but cannot discover a reconciling and mediating basis, it gives birth to a dreary and fanatic enthusiasm which breaks forth in self-mutilation or - as in the case of the priests of the Phrygian goddess - in self-emasculation, which in philosophy is accomplished by

9 Id., Philosophical Inquiries into the Essence of Human Freedom, trans. James Gutmann, Chicago: Open Court, 2003, p. 25. [Id., Sämmtliche Werke, Bd. VII, Stuttgart: J.G. Cotta'scher Verlag, 1860, p. 356: „Die ganze neu-europäische Philosophie seit ihrem Beginn (durch Descartes) hat diesen gemeinschaftlichen Mangel, daß die Natur für sie nicht vorhanden ist, und daß es ihr am lebendigen Grunde fehlt."]

10 And it is abstraction in particular that is the murder weapon here. The diagnosis passage from the Freiheitsschrift accuses realisms and idealisms that operate according to the assumption that the real and the ideal principles are separate, of precisely being too lifelessly abstract as long as the real (i.e. Nature) is not taken as the foundation of the ideal. 
the renunciation of reason and science. ${ }^{11}$

This real principle which is to serve as the vital ground of philosophy is nature. The abstraction here is separating nature from philosophy, from thinking, from what is mistakenly taken to be distinctly and exclusively human. This separation, which indeed began with Descartes' dualism and continued with the idealism/realism archrivalry, found a strange inverted resolution in Kant, whereby nature became dependent on conditions of experience. This has yet again taken place through abstraction - abstraction $^{12}$ of the human from the natural conditions of experience. The result of all this abstraction is physiocide, but it is also sui/anthropocide - insofar it leads to humanity uprooted from nature, left unable to think its material grounds and what sort of beings its members are. Abstraction, therefore, suggests itself as a problem, and posits itself persistently whenever the sphere of nature is limited and nature is not taken to ground the human. The result - a philosophy that begins with and in abstraction instead of beginning in a real ground - would be, as Schelling argues, merely negative, "flee[ing] into a complete wasteland devoid of all being."13 And yet, abstraction is a double-edged sword. In this part of the paper, I will determine what abstraction is for Schelling, through an examination of the First Outline and Darstellung des Naturprozesses. Moreover, I will present a reading of Schelling's late philosophy of natural process according to which the elements of the process are abstractions. They are, however, abstractions not in the sense of being mental cutouts made for human convenience and/or thought-experimentation, but rather function as abstract

11 Ibid. [Id., Sämmtliche Werke, Bd. VII, pp. 356-357: „Spinozas Realismus ist dadurch so abstrakt als der Idealismus des Leibniz. Idealismus ist Seele der Philosophie; Realismus ihr Leib; nur beide zusammen machen ein lebendiges Ganzes aus. Nie kann der letzte das Princip hergeben, aber er muß Grund und Mittel seyn, worin jener sich verwirklicht, Fleisch und Blut annimmt. Fehlt einer Philosophie dieses lebendige Fundament, welches gewöhnlich ein Zeichen ist, daß auch das ideelle Princip in ihr ursprünglich nur schwach wirksam war: so verliert sie sich in jene Systeme, deren abgezogene Begriffe von Aseität, Modificationen u.s.w. mit der Lebenskraft und Fülle der Wirklichkeit in dem schneidendsten Contrast stehen. Wo aber das ideelle Princip wirklich in hohem Maße kräftig wirkt, aber die versöhnende und vermittelnde Basis nicht finden kann, da erzeugt es einen trüben und wilden Enthusiasmus, der in Selbstzerfleischung, oder, wie bei den Priestern der phrygischen Göttin, in Selbstentmannung ausbricht, welche in der Philosophie durch das Aufgeben von Vernunft und Wissenschaft vollbracht wird."]

12 "Abstract" after all comes from Latin abstrahere, "draw away".

13 F.W.J. Schelling, The Grounding of Positive Philosophy, trans. Bruce Matthews, New York: SUNY Press, 2007, p. 142. [Id., Sämmtliche Werke, Bd. XIII, Stuttgart: J.G. Cotta'scher Verlag, 1858, p.76: "um in eine völlige Wüste alles Seyns zu fliehen".] 
stages of the process of temporal production, and are thus abstractions that move natural process forward. As a result of this discussion, it should then become clear that thinking about abstraction is not itself necessarily an abstraction. That abstraction can be thought of as processual, dynamic and positive; that it - short of being a hindrance or disease which leads to the denial of our natural material ground, the death of nature and the pathological entrapment of the mind within the sterile limited sphere of a certain kind of philosophy - is nothing but itself part of nature. Abstraction will be demonstrated to be tied inextricably with reality.

The idea of nature as composed of "bits" of power in Schelling goes all the way to the aforementioned First Outline, where to think the unconditioned that is nature, Schelling introduces abstract atoms - "simple actants:"

What IS in space is in space by means of a continually active filling-up of space; therefore, in every part of space there is moving force, so also mobility, and thus infinite divisibility of each part of matter, no matter how small, from all the remaining ones. The original actants, however, ARE not themselves in space; they cannot be viewed as parts of matter. Accordingly, our claim can be called the principle of dynamic atomism. For us, every original actant is just like the atom for the corpuscular philosopher; truly singular, each is in itself whole and sealed-off, and represents, as it were, a natural monad. ${ }^{14}$

The footnote to this paragraph is also important:

If the evolution of Nature were ever complete (which is impossible), then after the general decomposition of each product into its factors nothing would be left other than simple factors, i.e. factors which are no longer themselves products. Therefore, these simple factors can only be thought as originary actants, or - if it is permissible to express it this way - as originary productivities.

Our opinion is thus not that there are such simple actants in Nature, but only that they are the ideal grounds of the explanation of quality.

14 Id., First Outline for a System of the Philosophy of Nature, pp. 20-21. [Id., Sämmtliche Werke, Bd. III, Stuttgart: J.G. Cotta'scher Verlag, 1858, pp. 22-23: „[W]as im Raum ist, ist im Raum nur vermittelst einer continuirlich-thätigen Raumerfüllung; in jedem Theil des Raums ist also bewegende Kraft, sonach auch Beweglichkeit, daher Trennbarkeit jedes noch so kleinen Theils der Materie von allen übrigen ins Unendliche. Die ursprünglichen Aktionen aber sind nicht selbst im Raum, sie können nicht als Theil der Materie angesehen werden 1 . Unsere Behauptung kann sonach Princip der dynamischen Atomistik heißen. Denn jede ursprüngliche Aktion ist für uns ebenso, wie der Atom für den Corpuscularphilosophen, wahrhaft individuell, jede ist in sich selbst ganz und beschlossen, und stellt gleichsam eine Naturmonade vor."] 
These simple actants do not really allow of demonstration - they do not exist; they are what one must posit in Nature, what one must think in Nature, in order to explain the originary qualities. Then we need only prove as much as we assert, namely, that such simple actions must be thought as ideal grounds of explanation of all quality, and we have provided this proof. ${ }^{15}$

Nature here is taken as consisting of ideal originary actants that are theoretical entities. Already here, Schelling is skeptical that static material mechanical atoms can explain the qualities in nature, and sees the need to resort to these dynamic atoms, each of them nothing but "a bit of force", "a unit of productivity." This later develops into what he will call his Potenzenlehre. Before I move on there, however, the key term of this paper - abstract, as it appears locally in the above passage - should be explained and qualified.

It is easy to read this above passage as demonstrating that Schelling, at least at some point in his long philosophical life, was a scientific anti-realist. He seems to be saying: "we philosophers need to explain quality, therefore we pragmatically postulate non-existent entities that help us understand and manipulate nature." In light of such a beginning to his naturphilosophische project, one can rightfully ask whether it makes any sense to talk about forces that stand behind the process of nature as opposed to thinking nature in terms of useful fictions. This is why we have to think about what makes primary actants in the above passage abstract, for despite appearances, Schelling is doing ontology in the First Outline.

If we look closely at the passage concerning simple actants, it is clear that they are that level of matter whereby it becomes indivisible. The lowest, the basic, the simple, the originary, the maximally decomposed. Their abstraction stems precisely from here: it is not that we don't know

15 Ibid., p. 21f. [Id., Sämmtliche Werke, Bd. III, Stuttgart: J.G. Cotta'scher Verlag, 1858, p. 23f: „Wäre die Evolution der Natur je vollendet (was unmöglich ist), so würde nach diesem allgemeinen Zertrennen jedes Produkts in seine Faktoren nichts übrig bleiben als einfache Faktoren, d.h. Faktoren, die nicht selbst mehr Produkte sind. Diese einfachen Faktoren können daher nur als ursprüngliche Aktionen, oder - wenn es erlaubt ist so sich auszudrücken - als ursprüngliche Produktivitäten gedacht werden.

Unsere Behauptung ist also nicht: es gebe in der Natur solche einfache Aktionen, sondern nur, sie seyen die ideellen Erklärungsgründe der Qualität. Diese einfachen Aktionen lassen sich nicht wirklich aufzeigen - sie existiren nicht, sie sind das, was man in der Natur setzen, in der Natur denken muß, um die ursprünglichen Qualitäten zu erklären. Wir brauchen also auch nur so viel zu beweisen, als wir behaupten, nämlich, daß solche einfache Aktionen gedacht werden müssen als ideelle Erklärungsgründe aller Qualität, und diesen Beweis haben wir gegeben."] 
whether these actants exist or not; this is not a Kantian access problem and Schelling is not digging here at the unfathomable depths of nature, forced to postulate something just to explain anything. The abstraction stems from the abstract stoppage of natural production at the level of these actants; what is abstract is that the Naturphilosoph drew a line after these actants and said that this was it. I have already mentioned in my introduction, that Schelling is a philosopher who avoided - and at times this has made him look quite slippery - drawing final lines and setting ultimate foundations, as he cannot conceive of a situation where such lines and foundations would not need lines and foundations in turn. Moreover, a somewhat similar reason is at stake for Schelling's refusal to draw the line at some level and declare that level to be the "fundamental" level of power, basic, simplest, below which there is no power. We could go "down" or "back" in thinking to ground the subjects of our investigation until we seem to have hit a level that seems to us to be basic, but it would be absolutely unclear how to proceed with the reverse direction; i.e., if below that line of ground there is no activity, how on earth did activity ever start at the line of ground? Schelling has no answer for something coming out of nothing, unsurprisingly.

As Iain Grant points out, we cannot think the inception of the universe. If we were to, then the universe-creation we would be thinking about would be different from the one that brought us here, the former (i.e. the one we are thinking about) being clearly consequent on the latter and on our existence. ${ }^{16}$ Any time a Naturphilosoph wants to think potencies, any beginning he would take would be, then, not a beginning in some absolute sense. Any attempt to turn those powers, those primary productivities, into units, and give them - as if it were in a physics lesson in middle school - points of application whereby they begin, would be as giving them merely local beginning, almost entirely arbitrary, like a line drawn by abstraction just to give the current investigation a starting point. Once again, the problem here, for Schelling, is not infinite regress - it would be that the stopping of the regress at any level would have no better justification than its stopping at any other level: i.e. convenience and the purposes of a specific investigation at hand. Schelling's "simple actants" from the First Outline are abstractions not because we are not able to tell whether they exist or not, not because we postulate them as thought-entities, but

16 See Iain Hamilton Grant, "Inflationary hypotheses: The construction of matter and the deep field problem", ed. S. Pfeffer, in Speculations on Anonymous Materials, Berlin: Merve, 2015. 
because we cut them off from their grounds and designate them as basic without any weightier ontological reason than provisional simplicity. ${ }^{17}$ True to Schelling's antipathy to atomism I have mentioned before, they are also "atoms" only in the sense that we treat them as such. Hence, when Schelling says that simple actants don't exist and are abstractions, then that means that they don't exist in nature as simple actants, not that there are no actants in nature tout court.

If we take the case of the simple actants as exemplary, we can say that abstraction consists in two moments. The first - very obvious - is localization and limitation: in order to draw something away from something else (an element from its context, a productivity from the chains of natural process/production), this context must first be at least minimally delimited. Abstraction, then, always begins with some kind of localization, with zooming into a node before its extraction. The simple actants are thoroughly localized at the deepest level of material nature possible. This moment of localization taken alone, however, is not yet abstraction, as locality - boundedness by antecedents and consequents ${ }^{18}-$ is the feature of anything and everything finite. True abstraction is when the localized node of the natural process is then taken to be somehow independent simple, basic or having undergone such a qualitative transformation while arising from whatever came before it, that it can shed the after-influence of its antecedent. Schelling invites us to temporarily consider the simple actants separately from any grounding principle, but rather the basis for explaining everything in nature. Such an element cannot but be abstract.

\section{Natur-Mord}

With this, we can look at how abstraction plays out in Schelling's later texts - in the networks of the Potenzenlehre. For simplification, I will only look at Schelling's latest texts dealing with the potencies and Nature, most prominently, the Darstellung des Naturprozesses and the Darstellung der Reinrationalen Philosophie. In those texts, Schelling operates with the

17 Saying here that nevertheless these primary actants are merely ideal, fictional explanatory entities just because Schelling decides to adopt them as units of productivity would be similar to claiming that gravity is merely ideal just because we think of it as a force of mutual attraction, while it is far from that scientifically simple and can be explained further.

18 On this, see Iain Hamilton Grant, "How Nature Came to Be Thought", Journal of the British Society for Phenomenology 44, 1 (2013), pp. 24-43. 
potencies using the notation $-\mathrm{A},+\mathrm{A}, \pm \mathrm{A}$, where $-\mathrm{A}$ is pure $\mathrm{Can}$, mere ability or subject of existence, $+\mathrm{A}$ is pure existence or object, and $\pm \mathrm{A}$ is the subject-object. While presenting this model, Schelling first gives its form, a bare-bones schematic of the three elements. The potencies operate as follows: -A is the material principle: ${ }^{19}$ unlimited, undefined, nothing in particular, the dark principle at the ground of creation, untouched by the light of reason. If we look back to ancient philosophy we find that a similar role is played by the Platonic unlimited, the apeiron. And just as the ancients' apeiron is offset by the peras, the limit introduced into it - which is how "real being" is generated ${ }^{20}$ - the pure Can, -A, is offset by $+\mathrm{A}$, " $d[a]$ s rein seyende." 21 -A strives towards $+\mathrm{A}$, which serves as an attractor, and thus as a determining force. If $+\mathrm{A}$ is to be described in any way - and a potency is probably best described functionally in terms of what its role in the cycle of natural processes is - then $+\mathrm{A}$ is most akin to Plato's Idea. It is something which sheerly exists, by virtue of which individual things individuate. The $-\mathrm{A}$ determined by the $+\mathrm{A}$ therefore produces $\pm \mathrm{A}$ as a result - a real individual being, which is simultaneously that which is, and that which has the capacity to be.

19 F.W.J. Schelling, , Sämmtliche Werke, Bd. XI, Stuttgart: J.G. Cotta'scher Verlag, 1856, p. 388: "[D]as Können als Schranke des Seyns gesetzt war, als das aus aller Schranke Getretene, an sich Grenz- und Bestimmungslose, also ganz gleich dem pythagorischen

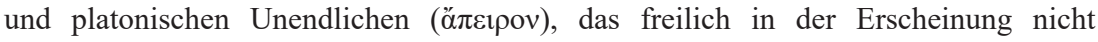
anzutreffen; denn alles Seyn, das in dieser sich findet, ist schon wieder ein in Schranken gefaßtes und begreifliches; indeß enthält die Erscheinung selbst Anzeichen, daß allem Seyn ein an sich schrankenloses, der Form und Regel widerstrebendes zu Grunde liegt. Dieses seiner selbst ohnmächtige, also für sich eigentlich nicht seyn könnende Seyn wird dennoch der Grund und Anfang seyn alles Werdens, und in aristotelischer Ausdrucksweise die erste, nämlich materiale Ursache alles Entstehenden. [[T]he Can was posited for it as a barrier to Being, as what finds egress from all barriers, the limitless and indeterminate in itself, entirely akin to the Pythagorean and Platonic infinite (ä $\pi \varepsilon(\rho) v)$, that, of course, is not to be found in appearance. For every Being situated in the infinite, is already in turn held behind barriers and is [thus] susceptible to being conceived. Meanwhile the appearance itself contains the mark that all Being is grounded in something in itself barrier free, striving against all form and rule. Itself impotent, so for itself properly not able to be being, it will nevertheless be the ground and beginning of all becoming, and in Aristotelian terms, the first, namely the material cause of all emergence."]

20 Plato, Philebus, tr. Benjamin Jowett, available from http://www.ellopos.net/elpenor/ greek-texts/ancient-greece/plato/plato-philebus.asp

21 F.W.J. Schelling, , Sämmtliche Werke, Bd. XI, p. 389. ["not yet a matter of actuality, but only of existing in the idea".] 
In this bare-bones schematic, Schelling then points out, "not yet a matter of actuality, but only of existing in the idea",22 i.e. it is negative, an abstraction. Taking this series of three elements is Schelling's attempt to clarify the form by cutting away from it as much content as possible, leaving solely a "reiner Vernunft-Organismus" or a "Vernunft-Idee." 23 In the hypothetically distilled and dissected unfolding of any natural process, the raw indeterminacy of sheer Can -A, the past "potency" which has already once spent its powers, the cold harsh raw determinacy and formalism of $+\mathrm{A}$ and the separate existence of their product $\pm \mathrm{A}$ are all abstractions, powerless and static. It is the simplified logical kernel of the Potenzenlehre, which is localized as an answer to the question of reason "What am I thinking when I think what exists?" ${ }^{4}$ The transition from thinking this reason-idea out of negativity and to thinking the world outside it is to "posit the first element of it as existing in itself" and then following its elements through the cycle of mutual extainment. To put this as simply as possible, the purereason-organism is to be plugged back in into the nets of the world just as it was previously surgically extracted. The Naturphilosoph extracts the mechanism to examine, understand, all the better localize and retrace it; when he understands the mechanism, he reconnects it with that which it is a mechanism of, and witnesses the natural process run before him in its full glory as a result. Without this reconnection, though, the formalistic core of Schelling's Potenzenlehre is an abstract representation of a natural process, no more; its separate elements are also no more than specks of abstraction unless put into a relationship of mutual extainment, i.e. unless they are allowed to have an effect.

This reconnection, "plugging back in", is however not some kind of pure "thinking potencies into existence." The point here is not to think hard enough until whatever thousand deadly abstract cuts you were making miraculously undo, fuse and concretize. The reconnection is rather one of excavation and navigation, tracing the productive history of whatever supposedly abstract element we are examining into both its future and the past. If we look at Schelling here:

[I] $f$ a world outside the idea is thought, then it can only be thought in this manner, and moreover can only be thought as such a world-outsidethe-idea. So in order to attain the world outside the idea we must first

\footnotetext{
2 Id., Sämmtliche Werke, Bd. X, Stuttgart: J.G. Cotta'scher Verlag, 1861, p. 305: „noch von keiner Wirklichkeit die Rede ist, nur vom Existirenden in der Idee."

23 Ibid., p. 306.

24 Ibid., p. 303: „Was denke ich, wenn ich das Existirende denke?”
} 
posit the first element of it as existing in itself, and the question is how this can be. Now we have, however, acknowledged from the outset that according to the idea, this subject is only directed to the higher object $(+A)$, not the subject or potency of itself, but precisely rather the existent, but according to its nature therefore it can equally only be this latter (potency of itself) directed away from infinite Being, in order to be the existent itself; in which respect this ability presents itself according to its nature as ambivalent nature, as $\Delta v a \varsigma$. But in that we think a goingout-of-itself of the idea, we must of course at the same time view this in the sense that, so that unity is indeed suspended, raised into making the transition to thought, but only from the perspective that it reconstitutes itself and precisely thereby makes itself actual and proves itself to be ineliminable. ${ }^{25}$

we see that in order to exit the negativity of the mere idea, Schelling suggests we treat the potencies not as a threefold unity, but also not as a disjointed threefold, but rather as an operative unity, dividing and reconstituting itself. This, combined with Schelling's persistent view that there is no basic level to nature, gives us the key as to what to do with abstraction to bring it back to life - ground it in its past and its future, ultimately ungrounding it in both directions. These operations of both past and futural grounding/ungrounding are inevitable, because whatever element we are examining cannot but have a causal history. Even abstract elements, even abstraction itself, they all have a ground.

The presentation of the potencies at the beginning of Darstellung des Naturprozesses is thus abstract only insofar as it is Schelling setting up a philosophical toolbox. Whenever the philosopher is to think abstractly and give abstraction justice, it is only possible through recognizing that, if abstraction means unconditional declaration of independence and auton-

25 Id., Sämmtliche Werke, Bd. X, p. 307: [W]enn eine Welt außer der Idee gedacht wird, so kann sie nur auf diese Weise, und kann dann ferner nur als eine solche gedacht werden. Um also zur Welt außer der Idee zu gelangen, müssen wir erst das erste Element derselben als für sich Seyendes setzen, und die Frage ist, wie dieß seyn könne. Nun haben wir aber gleich anfangs erkannt, daß jenes Subjekt zwar der Idee nach nur dem höheren Objekt (+A) zugewendet, nicht Subjekt oder Potenz seiner selbst, sondern eben des Existirenden sey, aber seiner Natur nach doch ebensowohl dieses (Potenz seiner selbst) seyn, vom unendlichen Seyn sich abwenden kann, um für sich selbst Seyendes zu seyn; in welchem Betracht dieses Können als die ihrer Natur nach zweideutige Natur, als $\Delta v \alpha \varsigma$, sich darstellt. Indem wir aber ein Auseinandergehen der Idee denken, müssen wir doch sie zugleich als unaufheblich in dem Sinne ansehen, daß die Einheit zwar suspendirt - vorübergehend im Gedanken aufgehoben werden kann, aber nur in der Absicht, daß sie sich wiederherstelle, aber eben damit verwirkliche, sich als die nicht aufzuhebende auch erweise. 
omy, then it can only be sterility and premeditated murder of whatever is abstracted. Abstraction is precisely local and conditional - conditional on the abstracted object's previous pluggedness into networked processes of concretion. This connection/disconnection is what distinguishes the use of abstraction as a surgical tool and its use as a weapon of murder, capable of killing everything, even itself, i.e., turning abstraction to meaningless isolation and sterility. The problem of Naturphilosophie, the weapon that attempts to strike down nature then, is not purely abstraction, but abstraction torn from the processes of natural production and unhinged from history.

$* * *$

F.W.J. Schelling's Naturphilosophie gives philosophy what is still a rather poorly-explored option - a concept of Nature as absolute productivity, one which is best thought of in terms of power. It is an answer to Kantian and mechanistic conceptions of nature, and while it may seem like this unconditioned nature is so unamenable to abstraction that there can, paradoxically, be no philosophical thought about it, this is far from the truth. I have attempted to show that Schelling takes abstraction to mean uprootedness from antecedents and consequences, and that once this uprootedeness is understood to be merely provisional, there is no obvious problem with his conception of Naturphilosophie, which is curiously viable (or at the very least has its viability pending) simply because it operates with a different understanding of nature. 


\section{Bibliography}

Grant, Iain Hamilton, "Does Nature stay what it is?", The Speculative Turn: Continental Materialism and Realism, eds. Levi Bryant, Graham Harman, Nick Srnicek, Melbourne: re.press, 2010.

— "Inflationary hypotheses: The construction of matter and the deep field problem", in Speculations on Anonymous Materials, ed. S. Pfeffer, Berlin: Merve, 2015.

— "How Nature Came to Be Thought", Journal of the British Society for Phenomenology 44, 1 (2013).

Kant, Immanuel, Critique of Pure Reason, trans. Paul Guyer and Allen W. Wood, Cambridge: Cambridge University Press, 1998.

Plato, Philebus, tr. Benjamin Jowett, available from http:/www.ellopos.net/elpenor/greek-texts/ancient-greece/plato/plato-philebus.asp

Schelling, F.W.J., Ages of the World, trans. Jason M. Wirth, New York: SUNY Press, 2000.

- First Outline for a System of the Philosophy of Nature, trans. Keith R. Peterson, New York: SUNY Press, 2004.

- Ideas for a Philosophy of Nature, trans. Peter Heath and Errol E. Harris, Cambridge: Cambridge University Press, 1995.

- Philosophical Inquiries into the Essence of Human Freedom, trans. James Gutmann, Chicago: Open Court, 2003.

— Sämmtliche Werke, Bd. X, Stuttgart: J.G. Cotta’scher Verlag, 1861.

— Sämmtliche Werke, Bd. XI, Stuttgart: J.G. Cotta'scher Verlag, 1856.

- The Grounding of Positive Philosophy, trans. Bruce Matthews, New York: SUNY Press, 2007. 


\begin{abstract}
In the Lectures on the Method of Academic Study in 1802, F.W.J. Schelling warned his listeners against the annihilation of nature. The annihilation he had in mind was not ecological in the usual sense of the word, but an annihilation caused by a certain way of looking at nature - a philosophical annihilation. The issue Schelling had in mind was that of understanding nature as mechanical, or as merely a domain of things, and of understanding humans as somehow more than natural. This paper is set to describe and argue for a Schellingian alternative to the "annihilation" of nature, to demonstrate why, on such an understanding of nature, the only thing which could undermine it is abstraction and to see how a philosophy should approach abstract thinking in order to deal with this apparent problem. For that, different ways to apply the "knife" of abstraction will be then discussed - some murderous, some surgical.
\end{abstract}

Keywords: Schelling - Naturphilosophie - Abstraction - Potency - Productivity

\title{
ZUSAMMENFASSUNG
}

In der Vorlesungen über die Methode des akademischen Studiums in 1802, warnte F.W.J. Schelling seine Zuhöher vor der „Annihiliation der Natur“. Diese gefürchtete Annihilation war nicht ekologisch in dem üblichen Sinn des Wortes, sondern verursacht durch eine gewisse Vorstellung von Natur, d.h., eine philosophiche Annihilation. Die problematische Vorstellung ist von Natur als etwas mechanisches, und von den Menschen als irgenwie mehr als natürlich. In was folgt beschreibe ich die schellingsche Alternative zu dieser Annihilation, demonstriere wieso und in welchem Sinn nur Abstraktion diese schellingsche Natur bedrohen kann und schlage vor, wie das philosophische Denken den Messer der Abstraktion verwenden soll, um dieses Problem zu vermeiden.

Schlusselwörter: Schelling - Naturphilosophie - Abstraktion - Potenz - Produktivität der Natur 